This is the accepted version of the following article: MAMUDU, H., CAIRNEY, P. and STUDLAR, D. (2015), GLOBAL PUBLIC POLICY: DOES THE NEW VENUE FOR TRANSNATIONAL TOBACCO CONTROL CHALLENGE THE OLD WAY OF DOING THINGS? Public Administration, 93: 856-873. doi: 10.1111/padm.12143, which has been published in final form at http://onlinelibrary.wiley.com/doi/10.1111/padm.12143/full. This article may be used for non-commercial purposes in accordance With Wiley Terms and Conditions for self-archiving. 
Hadii M. Mamudu, Assistant Professor of Public Health, East Tennessee State University mamudu@etsu.edu

Paul Cairney, Professor of Politics and Public Policy, University of Stirling, p.a.cairney@stir.ac.uk

Donley T. Studlar, Professor of Political Science, University of Strathclyde donley.studlar@strath.ac.uk

\title{
Global Public Policy: does the new venue for transnational tobacco control challenge the old way of doing things?
}

\begin{abstract}
The World Health Organization has fostered a new global public policy - the Framework Convention for Tobacco Control. Until the 1980s, tobacco control was the sole preserve of states. Now, most countries accept the transnational nature of policy. We explain this shift by identifying mutually-reinforcing changes in key policy process elements: transnational actors became a source of policy learning; an international venue 'institutionalised' new policies; networks began to include tobacco control groups and exclude tobacco companies; socioeconomic shifts undermined the public support, and economic case, for tobacco; and; the dissemination of scientific evidence helped actors reframe the image of tobacco, from an economic good to a health crisis. These elements combined to produce an environment conducive to 'comprehensive' tobacco control. Yet, the implementation of the FCTC has been slow and uneven, reflecting the continued importance of domestic policy environments, most of which are not as conducive to major policy change.
\end{abstract}

\section{Introduction: a new policy environment for global tobacco control}

Tobacco represents one of the most significant examples of global public policy. Most countries formally recognize the transnational nature of policy and have made a commitment to address it at a global level. Many international organisations contribute to a sense of global policymaking, including the World Conference on Tobacco or Health (WCTOH), the Organization of Economic Cooperation and Development (OECD), the World Bank, and the European Union (EU). The World Health Organization (WHO), in particular, has emerged as the key player. It has overseen the development of a global tobacco control policy and is at the heart of efforts to ensure implementation. Yet, there is a large gap between the global agreement and domestic outcomes, which could take decades to fill.

In this article, we argue that established policy theory can make a major contribution to the study of global policy. Although most policy theory is grounded in the study of individual states (Stone and Ladi, 2015), it has generated 'universal' concepts that can be used to compare global and domestic processes. Rather than testing the value of one theory, or comparative value of several, we identify the concepts used by most major theories to explain policy change - agendas, institutions, networks, socioeconomic conditions, and ideas (Cairney et al. 2012). These concepts help us guide empirical examination, not only of domestic, but also global, policy change. 
First, we synthesize 'evolutionary' policy theory (including punctuated equilibrium, multiple streams analysis and complexity theory) to explain the relationship between policy environments and policymaker choices.

Second, we argue that a policy environment most conducive to tobacco control can be found at the global level (and in 'leading' countries). We identify the current status of global tobacco control, focusing on the WHO as the international organization driving tobacco control, and the FCTC as the treaty setting out a detailed plan. We outline the factors which contributed to a major change in the policymaking environment. Actors pursuing strong tobacco control policies are now much more likely to find a favourable audience than they were before the 1980s. There have been important institutional changes. Responsibility for tobacco control has shifted, from being the sole preserve of individual countries to being led by the WHO. Unlike trade organisations in the UN, the 'standard operating procedures' of the WHO are geared towards tobacco control. The status of pressure participants has shifted markedly. The WHO has sought to exclude pro-tobacco groups from the policy process. The socioeconomic context has shifted: tobacco is less likely to be seen as an economic good, and surveys now demonstrate majority public support for the FCTC. Tobacco control rose on the global policy agenda, and it is now framed primarily as a major public health problem. A paradigmatic shift in the way that policymakers understand tobacco, from an economic product to be encouraged, to a harmful practice to be controlled, has been underpinned by the accumulation and 'institutionalization' of the scientific evidence linking tobacco to ill health. Although we separate these elements of the policy process analytically, we argue that it is problematic to simply separate their relative effects or trace the starting point of this transformation to one or several elements - as is common in, for example, quantitative analysis used to test narrow hypotheses. Rather, these environmental changes are mutually reinforcing.

Third, we argue that there is an 'implementation gap' between the agenda set by the FCTC and change on the ground. We provide data to demonstrate the size of the gap. We identify the variable extent to which the policymaking environments in individual countries are as conducive to change as at the global level. We initially use the developed/ developing country distinction, to show how this process is often framed in the public health literature. However, we do not use economic or democratic development to explain outcomes - largely because there are too many exceptions to rely on such a general explanation. Rather, drawing on policy theory, we identify policy environments that are more or less conducive to change contrasting the global environment, and that of a small number of 'leading' countries, with countries such as China and India with less extensive tobacco control.

Overall, we show that the FCTC marks the beginning of a long and uncertain process, which is coordinated by the WHO but led by individual states. Consequently, the term 'global public policy' should be treated with caution. Currently, it refers to the role of the FCTC primarily to set the agenda. In many respects, countries are still 
the main determinants of outcomes and the policy change envisaged by the WHO could take decades to produce or fail to materialize.

\section{Same Policy Choices, Different Environments?}

Policymaking environments have a major effect on the development and fate of policy choices. Most countries support the FCTC, but policymakers in each country face very different contexts as they proceed with implementation. Our focus shifts, from the new relationships and shared aims in the global arena, to the old ways of doing things in domestic politics. This aspect of policymaking is captured well by 'evolutionary' theories at the heart of public policy analysis, including multiple streams analysis, punctuated equilibrium theory and complexity theory (Cairney, 2012b). Yet, their references to 'evolution' and 'environments' are often vague and metaphorical; our contribution is to specify the factors involved in the dynamics of policy change.

Evolutionary theories describe two relevant processes (Cairney, 2013). First, the cumulative, long term development of policy ideas may be disrupted by major changes in the way that policymakers think about, and try to solve, policy problems. This disruption may be the aim of an international agreement. Second, policy change may only occur when a number of factors combine to create a conducive policy environment - a process that can be linked analytically to the wider evolutionary focus on the 'variation, selection and retention' of ideas. This may be the stumbling block to international agreement implementation: an environment conducive to change may be found at the international, but not the domestic, level.

These issues are articulated in several ways in the literature. Punctuated equilibrium theory (Baumgartner and Jones, 1993; 2009; Jones and Baumgartner, 2005; True et al, 2007) suggests that the international arena provides an alternative 'venue' for those seeking major policy changes; actors dissatisfied with progress in their own country may find greater success in international arenas less bound to historical policy images and path dependent institutions. The international arena may help short-cut the evolution of ideas; solutions that took generations to produce in some countries may be imported - through an international agreement - by other countries yet to face the same policy problems. Consequently, we may find that policy change is more rapid following global action.

However, the effect of international agreements may be undermined during implementation. Domestic governments face the need to make new solutions consistent with existing practices (Kingdon, 1984: 138-46; 1995: 165-6). This requirement is occasionally challenged domestically during policy 'punctuations' when, for example, crises or profound policy failures help break down institutions and ways of thinking (Hall, 1993; compare with Palier, 2005: 129; Streeck and Thelen; 2005: 9; Beland and Cox, 2010; Hay, 2002: 163). In the absence of challenge, a new solution must be introduced within the existing order, subject to influence by the domestic actors responsible for its implementation. An international agreement may act as a challenge to past decisions, but it represents one of many influences on implementation. 
Complexity theory allows us to move beyond the idea that policymaking is a linear process, beginning with the agreement and ending with its implementation, towards a focus on the constant interaction between domestic and international actors, producing less predictable policy outcomes (Geyer and Rihani, 2010: 12; Lewis and Steinmo, 2008; Mittleton-Kelly, 2003: 26; Cairney, 2012b; Cairney, 2012a: 125-6). Implementation is the outcome that 'emerges' from the interaction between international and national actors who follow different rules in different venues. The international arena provides an environment conducive to the selection of particular ideas. However, the subsequent 'retention process' may be dominated by domestic actors and organisations which adhere to different ways of thinking. If we treat implementation as a form of policy choice, our focus returns to the 'selection' process, as we consider the domestic policy environment and the advantages it provides to other ideas.

\section{Evolution and the Conditions for Policy Implementation}

These insights can be linked to a previous generation of studies of implementation and governance (Cairney, 2012a: 34-8). From a 'top down' perspective, we may expect the 'implementation gap' to be wide if the aims of the policy are not clear, there are insufficient resources devoted to its delivery, implementing officials use their discretion to pursue other aims, the policy is obstructed by powerful groups and socioeconomic conditions undermine delivery (Pressman and Wildavsky 1984). From a 'bottom up' perspective, policy from the top may represent one source of direction in a policy environment consisting of multiple actors with different interests. This is true even when we identify an authoritative actor such as a central government. It is even more important in the absence of a single driving force for an international agreement. The power to implement is the power to influence policy choices in a domestic environment which may favour longstanding ideas and behaviour (Lipsky 1980).

However, traditional approaches to implementation do not specify the nature of a policy environment. To advance our understanding of the environment in which policymakers operate, we disaggregate the policy process analytically into 'five core causal processes' used by most major policy theories to explain change (John 2003: 488; Cairney, 2014).

Institutions refers to regular patterns of behaviour and the rules, norms, practices and relationships that influence such behaviour (Cairney, 2012a: 69). Political systems contain multiple institutions, with formal and informal rules, and disperse power across levels and multiple levels of government. The successful implementation of policy may depend on giving primary responsibility to a particular part of government, such as a department sympathetic to the agreement's aims, whose rules are supportive of the policy. Networks refers to the relationships between actors responsible for policy decisions and the 'pressure participants' (Jordan et al, 2004) with which they consult and negotiate. Government departments have operating procedures that favour particular sources of evidence and some participants; the power of participants will depend on the department with primary responsibility. Socioeconomic process refers to the conditions that policymakers take into account when identifying problems and solutions. Relevant factors include a political 
system's demographic profile, economy and mass attitudes and behaviour. Ideas describes two related processes: the way that a problem is framed or understood, and therefore how much attention it receives and how it is solved; and, the beliefs that actors share. Policy choices take place within this context and the mutually reinforcing interaction between these factors that produce policy environments more or less conducive to policy changes.

In some countries, we find that the domestic policy environment is similar to the international environment. 'Leading' countries have gone through a long, gradual, process of evolution (over decades) that produces the conditions most conducive to sustained, major policy change. We find: one or more domestic venues sympathetic to the aims of the international agreement; that the actors most responsible for implementation are the most sympathetic to its aims; and, evidence of a 'paradigm shift' in some countries, providing a new language and set of ideas conducive to implementation. Further, the environment is crucial to success: the resources devoted to implementation rely on a sympathetic responsible institution; levels of effective support or opposition depend on the balance of power within policy networks; social attitudes and economic costs influence commitment to a policy; and, the successful transfer of new ideas depends on their relationship to the most accepted knowledge, or dominant understanding of the problem, in the importing country.

The process of implementation is less certain in 'laggard' countries. An international agreement does not guarantee the acceleration of policy change. Ironically, the countries most dependent on policy change driven at the international level may be the least able to implement. This point does not relate to the recalcitrance of countries during and after international negotiations. Rather, country representatives may form part of a supportive coalition during international negotiations, only to find a series of obstacles when they return to less favourable domestic environments.

\section{Global Tobacco Control: the role of the FCTC and WHO}

A policy environment conducive to tobacco control can now be found at the global level. The FCTC symbolises a major strengthening of global policy. It was developed in 2003 to promote comprehensive tobacco control, combining a wide range of measures:

- Tobacco taxation policy - price and tax measures to reduce demand for tobacco

- Smoke-free policy - protection from exposure to secondhand smoke

- Tobacco product regulation - regulation of contents of products (toxic ingredients)

- Ingredient disclosure - regulation of public tobacco product disclosures

- Health warning labels - at least $30 \%$ of the package of tobacco products should be a health warning

- Education and advocacy - to improve health education, communication, training and public awareness

- Banning tobacco advertising, promotion and sponsorship

- Smoking cessation services

- Prohibiting the illicit trade in tobacco products 
- Banning tobacco sales to minors (under 18)

- Litigation against tobacco companies

- Research to monitor and evaluate tobacco control

- Support for economically viable alternatives to tobacco growing

In 2005, it came into force as an international law embodying obligatory and hortatory provisions. It was designed to go beyond 'soft law', in which countries agree broadly to follow codes of conduct and non-binding instruments. While there is always uncertainty about how 'hard laws' can be implemented in individual countries, the FCTC was designed to fulfil this function, producing an overarching treaty, a minimum standard, and specific policy aims for ratifying countries to follow (Taylor and Roemer, 1996). As of October 2014, it has been ratified by 178 State Parties and one regional party (the EU) - one of the fastest and most broadly accepted treaties in the UN system. ${ }^{\mathrm{i}}$

Since the FCTC was adopted, the WHO has become the epicenter for the governance of tobacco control (WHO 2006). At the core of this system are tobacco-related units created within the WHO. The Tobacco-Free Initiative (TFI), the WHO's technical arm responsible for tobacco control, provided the impetus for the FCTC under Director-General Gro-Harlem Brundtland (Roemer et al. 2005, Yach 2014). The FCTC created the Conference of the Parties (COP), the governing body made up of ratified countries; and the Convention Secretariat, the administrative arm, to oversee the FCTC. Through these units, the WHO interacts with partners to facilitate national efforts to address tobacco use. This is transnational public policymaking largely independent of the constituent states (figure 1).

\section{Figure 1: The Administration of the FCTC}

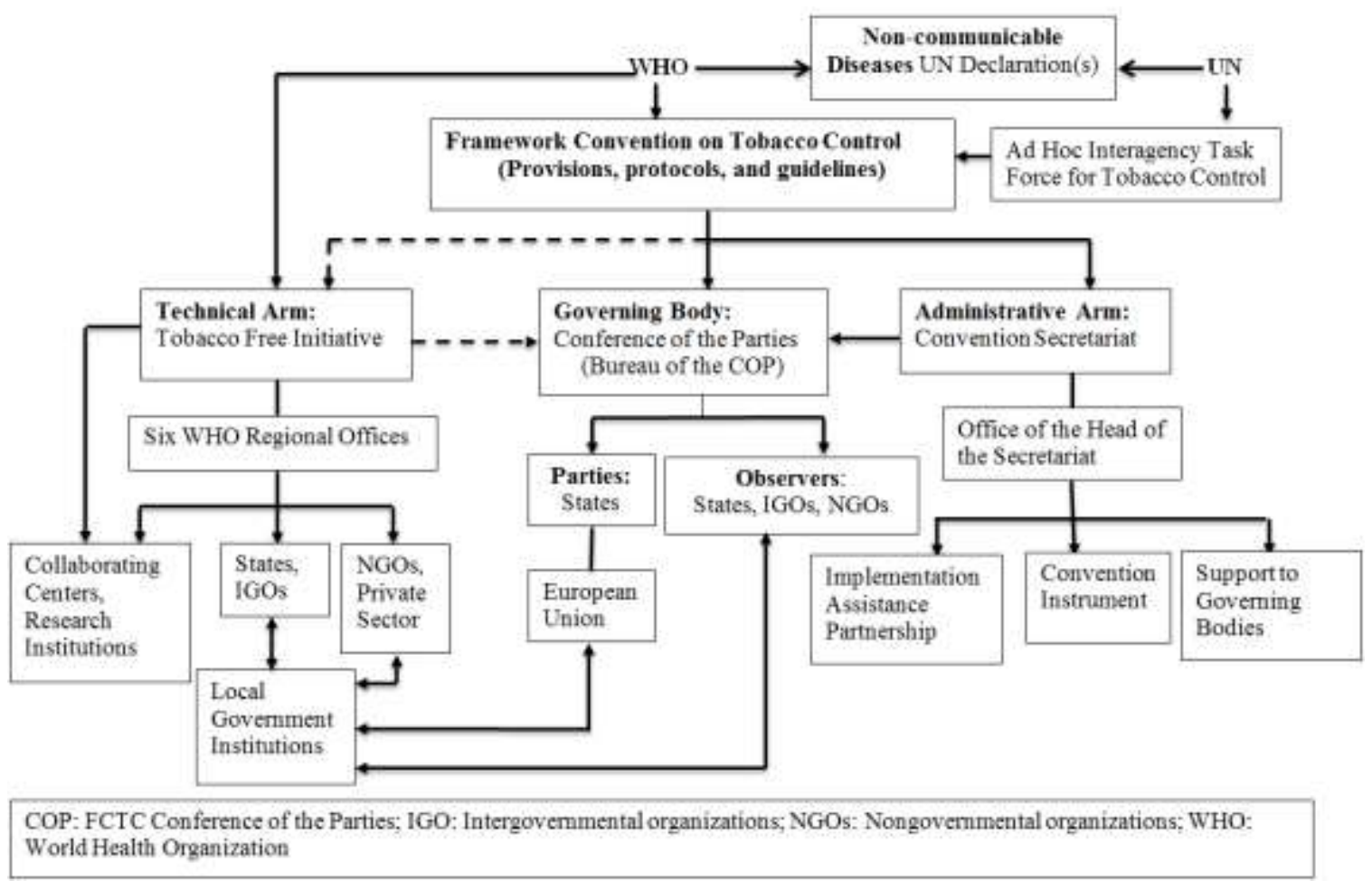


Note the widespread involvement of intergovernmental organizations (IGOs) such as the UN and its agencies. The COP performs several functions, including the development of guidelines for the FCTC provisions (seven as of May 2014 - WHO 2013b) and protocols (WHO 2013a). It works with the FCTC Parties (ratified countries), observers (non-ratified countries, including the US), IGOs such as the World Trade Organization (WTO), and accredited NGOs (COP 2006). The Convention Secretariat runs the day-to-day affairs of the FCTC, serving the COP and monitoring implementation. This global administration system interacts with states to ensure that the FCTC and its guidelines are implemented.

\section{A Changing Global Policymaking Environment: institutional change}

This development marks a fundamental shift in policy, and policymaking, in the postwar era. The WHO was created by states under Article 57 of the UN Charter as a specialized agency responsible for health, in 1948 (WHO 2006). It was involved in cancer-related issues prior to the 1970s, but often peripheral to tobacco policy. Its active role started with the 1970 resolution "WHA23.32 Health Consequences of Smoking" (WHO 1970) but, between the 1970s and early late 1990s, different IGOs and UN agencies, including the Food and Agricultural Organization (FAO) and the World Bank were involved, and they had conflicting orientations and goals. The FAO and World Bank treated tobacco as an economically beneficial commodity essential for developing countries. When the UN Focal Point for tobacco control was created in the early 1990s, it was located in UN Conference on Trade and Development (UNCTAD), where tobacco interests had influence (Yach and Bettcher 2000).

These dynamics changed in the late 1990s with the creation of the TFI as an executive unit within the WHO, and the UN Secretary General and the WHO Director General working to create the UN Ad Hoc Interagency Task Force for Tobacco Control, with the WHO as the host and leading UN agency. The WHO's role changed markedly between the 1970s and 2003: from a producer of scientific knowledge on tobacco use and control for Member States, to a leader in collective action among states (Cairney et al 2012, Yach 2014). Since the FCTC was adopted, the UN and its agencies have deferred to the WHO on tobacco control (UN General Assembly 2011). This is a crucial institutional shift, since the 'standard operating procedures' of the WHO - for example, to treat tobacco as a health problem and consult primarily with anti-tobacco groups - have differed markedly from many states and economic units within the UN.

\section{Networks: a shift in the balance of power}

'Policy networks' describes the relationships between governmental and nongovernmental actors. In tobacco, these links are binary; there exist two networks that operate increasingly independently of each other. There has been a historical contest between the tobacco network (seeking to promote the use and spread of tobacco products or production, including tobacco companies), and the tobacco control network (seeking to curtail the use of tobacco products, including NGOs, academe, and philanthropies). From the 1970s-1990s, when tobacco control was state-controlled and the WHO acted as an information hub, the tobacco network was a major force. The WHO worked with expert committees to develop the knowledge base for 
tobacco control, and NGOs to diffuse tobacco control policies, but the tobacco network was in a strong position to challenge controls (Cairney et al. 2012, Saloojee and Dagli 2000, WHO 2000).

The influence of tobacco interests started to wane in the 1990s. A general shift in attitude, prompted by the accumulation of scientific evidence on the negative health and economic effects of tobacco use, was accelerated by actions taken against tobacco by IGOs, including the World Bank (Mamudu et al. 2008). The shift was almost complete following the election of WHO Director General Brundtland and the subsequent creation of the TFI that targeted the tobacco industry as the 'nemesis' of tobacco control (Yach 2014). To tilt the balance in favor of the tobacco control network, the TFI provided the platform for the Framework Convention Alliance (FCA), a coalition of NGOs for the development and implementation of the FCTC (Mamudu and Glantz 2009, Yach 2014).

The FCTC process consolidated this shift. The guideline for Article 5.3 prohibited the participation of the tobacco industry in WHO processes and encouraged Member States to follow suit (WHO 2003; 2013b). These efforts have been affirmed by the UN (UN General Assembly 2011). As a result, none of the 26 NGOs accredited to the COP have ties to the tobacco industry (COP 2014). The global tobacco control occurs without formal industry involvement (Cairney and Mamudu 2014), which is unlike the domestic policy arena, or many other issue areas in global public policy (Stone and Ladi, 2015).

In contrast, several measures - Article 4.7 of the FCTC (WHO 2003, p.7), the COP's rules of procedures (COP 2006), and the ECOSOC resolution 1996/31 (ECOSOC 1996) - ensure that the tobacco control network has been involved regularly. The strength of this network has been enhanced by the involvement of large philanthropies and funding agencies (Yach 2014). Additionally, international and Western-based NGOs support the emergence of regional and country-based NGOs. The major shift facilitated by the FCTC has continued, with NGOs having observer status, and partnerships developing between the WHO and philanthropies. This has created a transnational public administration system where there is consensus for tobacco control (although the tobacco industry continues to explore avenues of influence). The tobacco control network has become the 'watchdog' for the FCTC, working to minimize tobacco industry influence by, for example, obliging key figures in tobacco control agencies and philanthropies to resign if they had links to the industry (Chapman 2011).

\section{Socioeconomics: a reduction in economic value and public opposition}

Much of the progress in tobacco control in countries in Western Europe and North America occurred amidst major socioeconomic changes, including a decline in tobacco use, reduced dependence on tobacco production and taxation, and favorable or 'permissive' public opinion. These changes helped policymakers become more receptive to tobacco control, with reduced concern about a major economic impact or popular backlash encouraged by tobacco interests. A classic case is United Kingdom (UK), in which there was a mutually reinforcing process of socioeconomic and policy change: tobacco taxation represented $16 \%$ of UK 
government income in 1950 , falling to $3.6 \%$ by 1996 ; smoking prevalence fell from $82 \% /$ $41 \%$ in men and women in 1948 to $22 \% / 21 \%$ in 2008; and, opinion polls eventually showed majority support for a smoking ban in most public places (Cairney et al. 2012: 115-7).

We can detect some global shifts in public opinion: the WHO worked to incorporate public opinion in the development of global policy during the FCTC negotiations, and these activities helped increase broad support for the FCTC (Mamudu and Glantz 2009; Montini et al. 2009; UN General Assembly 2011).

However, the socioeconomic picture is less clear at the global scale, with some countries exhibiting rising smoking despite often-high support for control. During the production of the FCTC, in many countries, smoking was often low but likely to rise, relatively few people could identify the risks of smoking, and the economic value of growing tobacco or manufacturing tobacco products was high. In this case, the FCTC represented a way for such countries to learn from the history and experience of 'leading' countries.

\section{Ideas and framing: shared scientific evidence on the problem and its solution}

The production of scientific evidence had a marked effect on problem definition. For most of the $20^{\text {th }}$ Century, when tobacco use and control was within the realm of states, the economic frame dominated policymaking, with the focus on employment and tax revenue for the government. This frame was promoted by the tobacco industry and allies such as the International Tobacco Growers' Association. The FAO and World Bank supported tobacco production, treating tobacco as an economically beneficial commodity.

The public health frame emerged with the accumulation of scientific evidence on the health and economic consequences of tobacco use. Some evidence on the negative health effects of smoking dates to the 1930s (Brandt 2007, Proctor 2000), but it gained major prominence with the reports of the UK Royal College of Physicians (1962) and the U.S. Surgeon General (1964). A global response emerged from the 1990s, with the ECOSOC resolution that requested the UN Secretary General to prepare and submit reports illuminating the negative effects of tobacco use, including health, economic and the environment (ECOSOC 1997). The pivotal evidence, challenging the economic value of tobacco, came from the World Bank (Author et al. 2012, Author et al. 2011b). In 1991/92, it stopped supporting tobacco projects, and worked with the WHO to publish Curbing the Epidemic to make an economic case for the FCTC in 1999 (Mamudu et al. 2008). The report challenged previous arguments that tobacco production could boost a country's economy (with a small number of exceptions). In combination with individual country reports (Jha and Chaloupka 2000), these activities shifted the emphasis from tobacco production towards control.

The public health frame was contested by the tobacco industry and its allies (Mamudu et al. 2008, Mamudu and Glantz 2009, Weishaar et al. 2012), which drew on the idea, for example, that tobacco production boosted the economy, and reduced health and social care costs when people die prematurely (ASH, 2013: 2). However, the public health frame was supported by a body of evidence - on the negative health effects of tobacco use (smoked and smokeless), 
including direct smoking, secondhand smoke exposure, and nicotine addiction; and negative economic costs, including direct and indirect healthcare costs - and an evidence-advocacy campaign that is difficult to match in other policy fields.

The WHO now has two major roles. First, it monitors tobacco use through the Global Tobacco Surveillance System (GTSS) and regular reports such as the MPOWER series. ${ }^{\text {ii }}$ The GTSS is a collaborative project between the WHO and bodies, including the Centers for Disease Control and Prevention (CDC), launched in 1999 to generate evidence in support of the FCTC (Warren et al. 2009). As of September 2014, the Global Youth Tobacco Survey, a core component of the GTSS, has been conducted over 359 times in 178 countries. With funding from Bloomberg Philanthropies and Bill and Melinda Gates Foundation, the Global Adult Tobacco Surveys (GATS) have been conducted in 22 countries (focusing on the countries with the highest smoking prevalence).

Second, the WHO is a hub for policy transfer. The transfer of ideas - as policy solutions, evaluated and found to be effective - has been central to global tobacco control, and the WHO's role has changed from a distributor of knowledge to an overseer of policy change. It has worked with tobacco control experts through a series of expert committees, Member States, IGOs, and NGOs to gather scientific knowledge about tobacco interventions. It disseminated ideas through World Health Assembly resolutions, its regional offices, seminars and workshops in member states, collaboration with other IGOs and UN agencies, and conferences, including the WCTOH.

Initially, ideas about tobacco control originated in jurisdictions that begun to experience the tobacco epidemic (Lopez et al. 1994, Thun et al. 2012), particularly those in Europe and North America (Roemer 1982, 1993). Until the FCTC, policy ideas were mostly transferred from within states to WHO and North-South. This trajectory has changed to include SouthSouth transfer of ideas among governments through a forum generated by the FCTC and its COP (WHO 2003). The proliferation of tobacco control NGOs worldwide has hastened the pace of diffusion. The emergence of tobacco control groups, such as the FCA with over 2000 affiliates worldwide (Cairney et al. 2012, Mamudu and Glantz 2009), and advocacy/social/professional networks such as the GLOBALink, facilitates the rapid diffusion of tobacco control ideas (Eriksen and Cerak 2008). The WHO became a conduit for this generation and diffusion of evidence-based policies, which became the basis for the development of the FCTC (Shibuya et al. 2003). The Member States of WHO, or Parties to the FCTC, are now expected to draw from this repertoire of tobacco control policies within their jurisdictions.

\section{From Global to Domestic Policymaking: the Implementation of the FCTC}

Implementation is still the responsibility of individual countries and, in many cases, the conducive policy environment that we identified at the global level is not replicated. Health departments are often key players, but they lack capacity and their voices are often drowned out by other departments, such as agriculture, finance and trade (Cairney et al. 2012). Tobacco policy arises on the policy agenda rarely and the public health frame competes with 
economic. Tobacco companies are powerful within networks and the capacity of anti-tobacco groups is often low (McCool et al. 2013, Tumwine 2011). The tobacco companies have the power and money to influence legislators (Patel et al. 2007) and challenge governments' legislative powers through litigation (Eriksen $\mathrm{M}$ et al. 2012). Tobacco growing and manufacturing is an important source of jobs, exports and revenue, and smoking prevalence is rising. The medical-scientific knowledge has had less of an effect on the policy agenda. Domestic anti-tobacco groups have the motivation but not the resources to ensure the acceptance of tobacco control ideas within their political systems (Cairney et al. 2012, McCool et al. 2013). These dynamics have helped produce a large and uneven gap between the expectations generated by global policymakers and the outcomes produced by domestic policymakers. This gap may be minimized over time, but could take decades.

\section{Moving beyond the Developed/ Developing country distinction}

On a global scale, a traditional starting point in public health studies is to note the uneven spread of tobacco control in 'developed' and 'developing' countries. The distinction is often used normatively, when describing successful but slow reductions of tobacco use in developed countries, and a chance to address policy problems before the 'epidemic' takes shape in developing countries.

Yet, this distinction masks significant variations in each category. Some developing countries, such as Brazil, Singapore, Thailand and Uruguay, have emerged as policy innovators in specific control measures. The developed country picture is also mixed, containing a group of 'leading' countries (Australia, Canada, Finland, Norway, Sweden, New Zealand, Ireland, the UK, and arguably the US) and 'laggard' countries (notably Japan and Germany). More importantly, it is difficult to operationalize 'developed country', to link economic or democratic development to policy change.

Rather, we focus on the role of policy environments more or less conducive to tobacco control. The developed/ developing country distinction, therefore, allows us to link our results initially to the established public health literature, but demonstrate how policy theory can take us beyond simple distinctions to offer clearer causal explanation.

The data in the following three tables demonstrate the need to shift our attention from international processes and agreements to domestic outcomes. In some countries, there is often little more than a formal commitment to implement. Table 1 outlines WHO evidence on the adoption of legislative policy instruments in key areas:

Table 1: Tobacco Policies in 'Developed' and 'Developing' Countries

\begin{tabular}{lllll}
\hline $\begin{array}{l}\text { Year } \\
\text { Tobacco control instruments }\end{array}$ & $\begin{array}{l}\text { Before 2000 } \\
\text { Developed } \\
(\mathbf{n = 3 1})\end{array}$ & $\begin{array}{l}\text { Developing* } \\
(\mathbf{n = 1 6 3 )}\end{array}$ & $\begin{array}{l}\text { By 2011 } \\
\text { Developed } \\
(\mathbf{n = 3 1})\end{array}$ & $\begin{array}{l}\text { Developing } \\
(\mathbf{n = 1 6 3 )}\end{array}$ \\
\hline \hline & $4(13 \%)$ & $9(6 \%)$ & $30(97 \%)$ & $157(96 \%)$
\end{tabular}




$\begin{array}{lllll}\text { Smoke-free policy** } & 18(58 \%) & 39(24 \%) & 31(100 \%) & 135(83 \%) \\ \text { Ingredients disclosure } & 7(23 \%) & 2(1 \%) & 9(29 \%) & 8(5 \%) \\ \text { Health warning labels } & 9(29 \%) & 19(12 \%) & 28(90 \%) & 129(79 \%) \\ \begin{array}{l}\text { Education and advocacy program } \\ \text { Ban on tobacco advertising, } \\ \text { promotion and sponsorship }\end{array} & 17(54 \%) & 26(16 \%) & 17(54 \%) & 37(23 \%) \\ \text { Tobacco cessation services } & 3(10 \%) & 0 & 29(94 \%) & 128(78 \%) \\ \begin{array}{l}\text { Prohibit illicit trade in tobacco } \\ \text { products }\end{array} & 0 & 1(0.01 \%) & 2(6 \%) & 6(100 \%) \\ \begin{array}{l}\text { Ban tobacco sales to minors } \\ \text { Litigation }\end{array} & 4(13 \%) & 5(3 \%) & 14(45 \%) & 36(22 \%) \\ \text { Funding for programs and research } & 4(13 \%) & 3(2 \%) & 4(13 \%) & 9(5 \%) \\ \text { National Tobacco Control Act } & 0 & 0 & 25(8 \%) & 146(90 \%)\end{array}$

*Classification based on UN Statistics Division categories. **Otherwise known as 'clean indoor air' policies. Sources: the tobacco laws website (http://www.tobaccocontrollaws.org/; (Muggli et al. 2013)) WHO MPOWER reports (WHO 2008, WHO 2009b, WHO 2011), WHO (WHO 1976), US National Clearinghouse for Smoking (1973).

It shows a large increase in the worldwide adoption of tobacco control measures since the FCTC negotiations began in 2000. However, the extent of tobacco control was not 'comprehensive' in many countries. The developed country experience is patchy, containing a small number of 'leaders' approaching comprehensive tobacco control and a larger number of countries with limited controls. Even in the leading countries, few had significant legislative controls before the 1980s (Mamudu et al. 2012). The use of legislation to control tobacco is generally less extensive in 'developing' countries, particularly in areas such as the regulation of ingredients disclosure, tobacco advertising and smoking in indoor public places.

This evidence is reinforced by two longer term measures of implementation: country reports by the Parties to the FCTC (Table 2) and reports based on expert opinion (Table 3). Table 2 shows the number and proportion of countries that submitted a report in the relevant year. As more countries begin to report for the first time, the overall adoption rate can appear to fall. Yet, these global figures still demonstrate a key finding: while the overall implementation of the FCTC has increased, it has been uneven. In spite of the overwhelming support of the FCTC by 'developing' countries during the negotiations, they generally lag behind 'developed' countries in its implementation (Cairney et al. 2012, Mamudu and Glantz 2009). There is variation by policy instrument within this broad picture. For example, globally, the most adopted policies are bans on tobacco sales to minors, and health warning labels, while the least adopted policy was ingredient disclosure. The WHO's (2010) overall analysis (of 135 countries) also suggests that there is slow progress in 'developed' and 'developing' countries to introduce meaningful smokefree regulations (14\% reported a comprehensive ban on smoking in public places).

\section{Table 2: FCTC Implementation in Developed and Developing Countries}




\section{Developed Developing}

\begin{tabular}{|c|c|c|c|c|c|c|c|}
\hline $\begin{array}{l}\text { Survey questions: Have you } \\
\text { adopted and implemented, where } \\
\text { appropriate, legislative, executive, } \\
\text { administrative or other measures: }\end{array}$ & & $\begin{array}{l}\text { 2-year } \\
(2007)\end{array}$ & $\begin{array}{l}\text { 5-year } \\
(2010)\end{array}$ & $\begin{array}{l}\text { 7-year } \\
\text { (2012) }\end{array}$ & $\begin{array}{l}\text { 2-year } \\
\text { (2007) }\end{array}$ & $\begin{array}{l}\text { 5-year } \\
\text { (2010) }\end{array}$ & $\begin{array}{l}\text { 7-year } \\
\text { (2012) }\end{array}$ \\
\hline $\begin{array}{l}\text { price policies on tobacco products } \\
\text { so as to contribute to the health } \\
\text { objectives aimed at reducing } \\
\text { tobacco consumption? }\end{array}$ & $\begin{array}{l}\text { Tobacco } \\
\text { taxation } \\
\text { policy }\end{array}$ & --- & $\begin{array}{l}19 / 22 \\
(86 \%)\end{array}$ & $\begin{array}{l}26 / 30 \\
(87 \%)\end{array}$ & --- & $\begin{array}{l}40 / 53 \\
(75 \%)\end{array}$ & $\begin{array}{l}67 / 10 \\
9 \\
(61 \%)\end{array}$ \\
\hline $\begin{array}{l}\text { programmes regulating the } \\
\text { contents of tobacco products?? }\end{array}$ & $\begin{array}{l}\text { Tobacco } \\
\text { product } \\
\text { regulation }\end{array}$ & $\begin{array}{l}17 / 26 \\
(65 \%)\end{array}$ & $\begin{array}{l}15 / 22 \\
(68 \%)\end{array}$ & $\begin{array}{l}19 / 27 \\
(70 \%)\end{array}$ & $\begin{array}{l}49 / 105 \\
(47 \%)\end{array}$ & $\begin{array}{l}35 / 58 \\
(60 \%)\end{array}$ & $\begin{array}{l}55 / 11 \\
6 \\
(47 \%)\end{array}$ \\
\hline $\begin{array}{l}\text { programmes requiring public } \\
\text { disclosure of information about } \\
\text { the emissions of tobacco } \\
\text { products? - Art. } 9\end{array}$ & $\begin{array}{l}\text { Ingredient } \\
\text { disclosure }\end{array}$ & --- & $\begin{array}{l}14 / 23 \\
(61 \%)\end{array}$ & $\begin{array}{l}15 / 27 \\
(56 \%)\end{array}$ & --- & $\begin{array}{l}28 / 57 \\
(49 \%)\end{array}$ & $\begin{array}{l}47 / 11 \\
3 \\
(42 \%)\end{array}$ \\
\hline $\begin{array}{l}\text { programmes requiring that each } \\
\text { unit packet and package of } \\
\text { tobacco products and any outside } \\
\text { packaging and labelling of such } \\
\text { products carry health warnings } \\
\text { describing the harmful effects of } \\
\text { tobacco use? }\end{array}$ & $\begin{array}{l}\text { Health } \\
\text { warning labels }\end{array}$ & --- & $\begin{array}{l}19 / 22 \\
(86 \%)\end{array}$ & $\begin{array}{l}24 / 27 \\
(89 \%)\end{array}$ & $\begin{array}{l}86 / 105 \\
(81 \%)\end{array}$ & $\begin{array}{l}53 / 57 \\
(93 \%)\end{array}$ & $\begin{array}{l}93 / 11 \\
6 \\
(80 \%)\end{array}$ \\
\hline $\begin{array}{llr}\text { programmes } & \text { instituting } & \text { a } \\
\text { comprehensive } & \text { ban on all tobacco } \\
\text { advertising, } & \text { promotion } & \text { and } \\
\text { sponsorship? } & & \end{array}$ & $\begin{array}{l}\text { Ban on } \\
\text { tobacco } \\
\text { advertising, } \\
\text { promotion and } \\
\text { sponsorship }\end{array}$ & $\begin{array}{l}20 / 26 \\
(77 \%)\end{array}$ & $\begin{array}{l}16 / 22 \\
(73 \%)\end{array}$ & $\begin{array}{l}23 / 27 \\
(85 \%)\end{array}$ & $\begin{array}{l}53 / 110 \\
(48 \%)\end{array}$ & $\begin{array}{l}35 / 59 \\
(59 \%)\end{array}$ & $\begin{array}{l}71 / 11 \\
77 \\
(60 \%)\end{array}$ \\
\hline 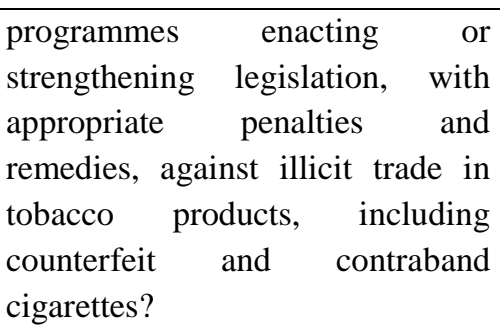 & $\begin{array}{l}\text { Prohibit illicit } \\
\text { trade in } \\
\text { tobacco } \\
\text { product }\end{array}$ & $\begin{array}{l}18 / 28 \\
(64 \%)\end{array}$ & $\begin{array}{l}18 / 20 \\
(90 \%)\end{array}$ & $\begin{array}{l}24 / 26 \\
(92 \%)\end{array}$ & $\begin{array}{l}68 / 109 \\
(62 \%)\end{array}$ & $\begin{array}{l}39 / 48 \\
(81 \%)\end{array}$ & $\begin{array}{l}71 / 96 \\
(74 \%)\end{array}$ \\
\hline $\begin{array}{l}--- \text { legislative, executive, } \\
\text { administrative or other measures } \\
\text { or have you implemented, where } \\
\text { appropriate, programmes } \\
\text { prohibiting the sales of tobacco } \\
\text { products to minors? }\end{array}$ & $\begin{array}{lr}\text { Ban } & \text { tobacco } \\
\text { sales } & \text { to } \\
\text { minors } & \end{array}$ & $\begin{array}{l}27 / 27 \\
(100 \%)\end{array}$ & $\begin{array}{l}21 / 21 \\
(100 \%)\end{array}$ & $\begin{array}{l}27 / 27 \\
(100 \%)\end{array}$ & $\begin{array}{l}82 / 109 \\
(75 \%)\end{array}$ & $\begin{array}{l}48 / 55 \\
(87 \%)\end{array}$ & $\begin{array}{l}97 / 11 \\
4 \\
(85 \%)\end{array}$ \\
\hline
\end{tabular}




\begin{tabular}{lllllllllll}
\hline--- & programmes developing & Funding for & $6 / 13$ & $19 / 22$ & 22 & Of & $31 / 65$ & $38 / 54$ & $69 / 11$ \\
and/or promoting research that & programs and & & & 27 & & & 3 \\
addresses determinants of tobacco & research & & $(46 \%)$ & $(86 \%)$ & & $(48 \%)$ & $(70 \%)$ & \\
consumption? & & & & $(82 \%)$ & & & $(61 \%)$
\end{tabular}

\begin{tabular}{|c|c|c|c|c|c|c|c|}
\hline $\begin{array}{l}\text { How comprehensive is the } \\
\text { protection from exposure to } \\
\text { tobacco smoke in }\end{array}$ & & & & & & & \\
\hline --- cultural facilities? & $\begin{array}{l}\text { Smoke-free } \\
\text { policies }\end{array}$ & $\begin{array}{l}26 / 27 \\
(96 \%)\end{array}$ & $\begin{array}{l}23 / 23 \\
(100 \%)\end{array}$ & $\begin{array}{l}26 / 26 \\
(100 \%)\end{array}$ & $\begin{array}{l}87 / 107 \\
(81 \%)\end{array}$ & $\begin{array}{l}49 / 53 \\
(93 \%)\end{array}$ & $\begin{array}{l}99 / 10 \\
8 \\
(92 \%)\end{array}$ \\
\hline --- shopping malls? & $\begin{array}{l}\text { Smoke-free } \\
\text { policies }\end{array}$ & --- & $\begin{array}{l}1 / 1 \\
(100 \%)\end{array}$ & $\begin{array}{l}24 / 24 \\
(100 \%)\end{array}$ & $\begin{array}{c}-- \\
-1\end{array}$ & $\begin{array}{l}7 / 8 \\
(88 \%)\end{array}$ & $\begin{array}{l}89 / 10 \\
0 \\
(89 \%)\end{array}$ \\
\hline --- pubs and bars? & $\begin{array}{l}\text { Smoke-free } \\
\text { policies }\end{array}$ & $\begin{array}{l}10 / 13 \\
(77 \%)\end{array}$ & $\begin{array}{l}21 / 22 \\
(95 \%)\end{array}$ & $\begin{array}{l}25 / 26 \\
(92 \%)\end{array}$ & --- & $\begin{array}{l}7 / 8 \\
(88 \%)\end{array}$ & $\begin{array}{l}89 / 10 \\
0 \\
(89 \%)\end{array}$ \\
\hline --- nightclubs? & $\begin{array}{l}\text { Smoke-free } \\
\text { policies }\end{array}$ & $\begin{array}{l}9 / 12 \\
(75 \%)\end{array}$ & $\begin{array}{l}22 / 23 \\
(95 \%)\end{array}$ & $\begin{array}{l}25 / 26 \\
(96 \%)\end{array}$ & $\begin{array}{l}32 / 54 \\
(56 \%)\end{array}$ & $\begin{array}{l}34 / 52 \\
(65 \%)\end{array}$ & $\begin{array}{l}66 / 10 \\
3 \\
(64 \%)\end{array}$ \\
\hline --- restaurants? & $\begin{array}{l}\text { Smoke-free } \\
\text { policies }\end{array}$ & $\begin{array}{l}24 / 27 \\
(89 \%)\end{array}$ & $\begin{array}{l}23 / 23 \\
(100 \%)\end{array}$ & $\begin{array}{l}26 / 26 \\
(100 \%)\end{array}$ & $\begin{array}{l}74 / 109 \\
(68 \%)\end{array}$ & $\begin{array}{l}47 / 55 \\
(85 \%)\end{array}$ & $\begin{array}{l}93 / 10 \\
8\end{array}$ \\
\hline
\end{tabular}

Source: the 2-year, 5-year and 7-year reports of the FCTC implementation by Parties. Notes: Percentages and proportions consist of FCTC Parties that reported 'yes' or 'no' to the questions; those that did not provide an answer or submit a report were not included. As more countries begin to report for the first time, the overall adoption rate can appear to fall. The response to the smoke-free policy questions included 'full' and 'partial' implementation. Both responses were recoded to indicate the existence of a smoke-free policy.

Table 3 presents a survey of expert opinion on tobacco control (105 respondents) conducted by Warner and Tam (2012). Each respondent provides a 'score' relating to policy progress. A score approaching 2 indicates a 'substantial' degree of meaningful policy adoption. A mean of around 1 suggests 'moderate' policy progress, while scores close to zero suggest 'non-existent or limited' policy progress in each area. The data suggest that there has been striking change in tobacco control in the periods before and after the development of the FCTC.

Table 3: Experts' Opinion on Tobacco Control Policy Adoption

\begin{tabular}{lllll}
\hline Tobacco Instruments & \multicolumn{2}{c}{ 'Developed' } & \multicolumn{3}{c}{ 'Developing' } \\
\hline \hline
\end{tabular}




\begin{tabular}{lllll} 
Tobacco taxation policy & 0.86 & 1.65 & 0.27 & 0.77 \\
Smoke-free policies & 0.63 & 1.85 & 0.03 & 0.94 \\
Tobacco product regulation & 0.29 & 0.92 & 0.02 & 0.30 \\
$\begin{array}{l}\text { Health warning labels } \\
\text { Ban on advertising, promotion and }\end{array}$ & 0.75 & 1.69 & 0.17 & 1.03 \\
sponsorship & 0.63 & 1.65 & 0.08 & 0.98 \\
Media counter advertising & 0.57 & 1.17 & 0.04 & 0.44 \\
$\begin{array}{l}\text { Public education/information } \\
\text { School health education }\end{array}$ & 1.04 & 1.48 & 0.34 & 0.94 \\
Tobacco cessation services & 1.09 & 1.29 & 0.33 & 0.75 \\
Prohibit illicit trade in tobacco & 0.48 & 1.31 & 0.07 & 0.35 \\
products & 0.16 & 0.91 & 0.04 & 0.33 \\
Ban tobacco sales to minors & 0.96 & 1.52 & 0.14 & 0.73 \\
\hline \hline
\end{tabular}

Source: adapted from Warner and Tam (2012)

These figures highlight the gap between most 'developed' and 'developing' countries; the former has introduced more 'substantial' policy change, while the latter group's policy change and enforcement is more likely to be 'non-existent', 'limited' or 'moderate' (Bitton 2012, Warner and Tam 2012).

\section{The Importance of China and India}

Tobacco control policy is not truly global without the two countries which account for almost half of the world's tobacco users (Cairney and Mamudu, 2014). These brief case studies also demonstrate a need to move beyond the 'developing' category to explore, in more depth, the policy environments in individual countries, which are not yet conducive to the policy change associated with the FCTC.

China has one third of the world's smokers and produces $38 \%$ of the world's tobacco (Eriksen et al, 2012). Although China supported the FCTC and has adopted most of its components, many aspects of its environment are not conducive to implementation (Jin, 2014; Lu et al, 2012; Redmon et al, 2013). China maintains a state monopoly over tobacco production, which provides $8-11 \%$ of government revenue. Tobacco control is low on the agenda and the health image competes with a strong economic image based on the importance of economic growth to the legitimacy of the government. Tobacco policy is led by an economic development agency which consults regularly with the tobacco industry, and the health ministry is 'sidelined' (Jin, 2014). Public health groups are neither well-resourced nor engaged - partly because the Chinese government has a tense relationship with NGOs (although note their recent entry through the Bloomberg's Global Tobacco Control Initiatives). Public and physician knowledge, and scientific capacity, is low (Wu, 2008; Koplan et al, 2013). Smoking rates are high among the hospital staff and police forces held responsible for the (poor) implementation of limited bans on smoking in public places (Wan et al, 2013).

While India has demonstrated a similar commitment to the FCTC and is a world leader in the regulation of tobacco use in the media (WHO, 2009), it has similar issues. There is unusually 
high potential for it to, 'continue to pass legislation that is poorly enforced and challenged in the courts' (Schwartz et al, 2011). India passed legislation to introduce a smoking ban in 2008, but the fine for non-compliance is lower than the equivalent loss of business for restaurant owners and there is 'inadequate surveillance' to ensure compliance. India lacks capacity in key areas, such as health education (public knowledge of the risks of smoking is patchy) and smoking cessation clinics. A large proportion of the public 'may not have ever engaged in discussion on the merits of tobacco control' and may still be relatively likely to obstruct change - by, for example, flouting smoke-free laws - and view tobacco production in positive terms (a point that applies to many countries - Mehl et al, 2005).

\section{Conclusion}

The FCTC represents one of the most important examples of global public policy. It contains measures which combine to produce 'comprehensive' tobacco control. Supported by the vast majority of UN countries, it is backed by an administrative machine to help turn this agreement into a set of concrete policies to be implemented in each country. This is a major development: a policy problem, once the sole preserve of states, has primarily become the responsibility of the WHO. Yet, there is an important gap between the global agenda and policies in the vast majority of countries. Only a small number have introduced a 'comprehensive' set of tobacco control measures to match those of the FCTC.

The benefit of using established policy theory to explain these developments is that it contains 'universal' concepts that can be used to compare global and domestic policy processes. We explain the current disconnect in global tobacco policy with reference to differences in global and domestic policy environments. Actors pursuing strong tobacco control are much more likely to find a favourable audience at the global level than in most individual countries. The global policy environment is more conducive to policy change. Responsibility for tobacco control has shifted to the WHO, a health promotion body geared towards global tobacco control while, in many countries, the health department competes with departments representing economic and trade interests, and more likely to view tobacco as a valuable economic product. The WHO excludes pro-tobacco groups from the policy process while, in many countries, tobacco growers are still important and tobacco companies influence political parties and governments. While tobacco control has risen on the global policy agenda, the FCTC is often low on the agenda of many countries.

These differences can also be observed in comparisons among countries: a small number of 'leading countries' have introduced mutually reinforcing changes: the acceptance of the scientific evidence helped governments reframe tobacco as a public health 'epidemic'; this image allowed health-promotion organizations to take the lead in policy networks; and, successful tobacco control, helping to reduce the number of tobacco users, reduced the economic value of tobacco and opposition to further control. This process is still in its infancy in other countries. There is a major 'implementation gap', and the history of tobacco control, in leading countries, suggests that it could take a generation to fill or the FCTC could help shorten the process considerably. 
Overall, we can identify the major, and growing, importance of global tobacco control. While the FCTC has not yet produced 'comprehensive tobacco control' in most countries, it has set the agenda for change, with the WHO representing a hub for the dissemination for policy solutions and the body charged with monitoring policy implementation. It has accelerated policy change in countries that may have taken decades to treat tobacco as a pressing public health problem. Few policy areas can match this level of meaningful activity at the global level.

\section{References}

ASH (2013) 'The economics of tobacco' (London: ASH) http://ash.org.uk/files/documents/ASH_121.pdf

Baumgartner, F and Jones, B 1993; 2009 Agendas and instability in American politics, $1^{\text {st }}$ and $2^{\text {nd }}$ ed., University of Chicago Press, Chicago, IL.

Brandt, A 2007, The cigarette century, Basic Books, New York, NY.

Cairney, P 2012a, Understanding Public Policy, Palgrave, Basingstoke.

Cairney, P 2012b, 'Complexity Theory in Political Science and Public Policy', Political Studies Review, vol. 10 no. 3, pp. 346-358.

Cairney, P 2013, 'What is Evolution and how does it Inform Policy Studies?', Policy and Politics, no. In press, .

Cairney, P, Studlar, D and Mamudu, H 2012, Global Tobacco Control, Palgrave McMillan, Basingstoke.

Cairney, P and Mamudu, H 2014, “'The Global Tobacco Control 'Endgame'”, Journal of Public Health Policy, 35, 506-517

Chapman, S 2011, 'Health and Philanthropy - the Tobacco Connection', Lancet, vol. 377 no. 9759, pp. 11-13.

COP2014, Nongovernmental organizations accredited as observers to the Conference of the Parties. http://www.who.int/fctc/cop/observers_ngo/en/

COP2006, First Conference of the Parties to the WHO Framework Convention of Tobacco Control.

http://apps.who.int/gb/fctc/PDF/cop1/cop1_06_cd_decisionsdocumentsauxiliaires-en.pdf

ECOSOC 1997, E/1997/67, Progress made in the implementation of multisectoral collaboration on tobacco or health, ECOSOC, New York. 
ECOSOC1996, E/1996/96: Resolution and Decisions of the Economic and Social Council. http://csonet.org/content/documents/199631.pdf

ECOSOC 1993, E/1993/ 79. Multisectoral Collaboration on Tobacco or Health, Philip Morris.

Eriksen M, Mackay J and Ross H 2012, The Tobacco Atlas, American Cancer Society and World Lung Foundation, Atlanta, GA.

Eriksen, MP and Cerak, RL 2008, 'The Diffusion and Impact of Clean Indoor Air Laws', Annual Rev Public Health, vol. 97 pp. 171-185.

Geyer R, Rihani S. 2010, Complexity and Public Policy. London, UK; Routledge-

Hall, P 1993, 'Policy Paradigms, Social Learning, and the State', Comparative Politics, vol. 25 no. 3, pp. 275-296.

Hay C 2002, Political Analysis, Basingstoke; Palgrave MacMillan-

Jha, P and Chaloupka, F (eds) 2000, Tobacco Control in Developing Countries, Oxford University Press, Oxford.

Jin, J 2014, Why FCTC Politics Have Not Been Implemented in China: Domestic Dyanmic and Tobacco Governance, Journal of Health Politics, Policy and Law, vol. 39 no. 3, pp. 633-666.

John P 2003, Is There Life After Policy Streams, Advocacy Coalitions, and Punctuations? Policy Studies Journal, vol. 31 no. 4, pp. 481-98.

Jones, B and Baumgartner, F 2005, The Politics of Attention, University of Chicago Press, Chicago, IL.

Jordan G, Halpin D, Maloney W 2004, Defining Interests: Disambiguation and the Need for New Distinctions? British Journal of Politics and International Relations, vol. 6 no. 2, pp. 195-212.

Kingdon, JW 1984; 1995, Agendas, Alternatives, and Public Policies, $1^{\text {st }}$ and $2^{\text {nd }}$ eds Harper Collins, New York, NY.

Koplan JP, Eriksen M, Chen L, Yang G. 2013, The value of research as a component of successful tobacco control in China. Tobacco Control 2013, vol. 22 Suppl 2, pp. ii1-3.

Krasner, S (ed) 1983, International Regimes, Cornell University Press, Ithaca. 
Lewis O, Steinmo S. 2008, Taking Evolution Seriously. Florence, Italy; European University Institute; 2008.

Lipsky, M 1980, Street-level Bureaucracy, Russell Sage Foundation, New York, NY.

Lopez, AD, Collishaw, NE and Piha, T 1994, 'A Descriptive Model of the Cigarette Epidemic in Developed Countries', Tobacco Control, vol. 3 pp. 242-47.

Lu J, Su M, Hong Z, Zhang T, Huang X, Wang B, et al. 2011, Implementation of the WHO Framework Convention on Tobacco Control in mainland China. Tobacco Control vol. 20, pp. 309-314.

Mamudu, HM, Hammond, R and Glantz, S 2008, 'Tobacco Industry Attempts to Counter the World Bank Report Curbing the Epidemic and Obstruct the WHO Framework Convention on Tobacco Control', Social Science and Medicine (1982), vol. 67 no. 11, pp. 1690-1699.

Mamudu, HM and Glantz, S 2009, 'Civil Society and the Negotiation of the Framework Convention on Tobacco Control', Global Public Health, vol. 4, pp. 150-168.

Mehl G, Wipfli H, Winch P Co 2005, Controlling tobacco: the vital role of local communities. Harvard International Review vol.27, pp. 54-58

McCool, J, McKenzie, J, Lyman, A, et al. 2013, 'Supporting Pacific Island Countries to Strengthen their Resistance to Tobacco Industry Interference in Tobacco Control', International Journal of Environmental Research and Public Health, vol. 10 no. 8, pp. 3424-3434.

Mitleton-Kelly E. Ten Principles of Complexity and Enabling Infrastructures. 2003, In: Mitleton-Kelly E, Complex Systems and Evolutionary Perspectives of Organisations Amsterdam, Netherlands: Elsevier.

Montini, T, George, A, Martin-Mollard, M, et al. 2009, 'The Role of Public Participation in Public Health Initiatives', Global Public Health, vol. 26, pp. 1-13.

Muggli, ME, Zheng, A, Liberman, J, et al. 2013, 'Tracking the Relevance of the WHO Framework Convention on Tobacco Control in Legislation and Litigation through the Online Resource, Tobacco Control Laws', Tobacco Control, vol. 28 no. 8, pp.457-60.

Nadelman,EA(1990) Global Prohibition Regimes: The Evolution of Norms in International Society International Organization vol. 44 no. 4, pp. 479-526.

Palier, B 2005, 'Ambiguous Agreement, Cumulative Change' in Beyond Continuity, eds. W Streeck and K Thelen, Oxford University Press, Oxford, UK. 
Patel, P, Collin, J and Gilmore, AB 2007, 'British American Tobacco and Public Policy in Kenya', Tobacco Control, vol. 16 no. 1, pp. e1.

Pressman, JL and Wildavsky, A 1984, Implementation, University of California Press, Berkeley, CA.

Proctor, RN 2000, The Nazi war on cancer, Princeton University Press, Princeton, NJ.

Redmon P, Chen LC, Wood JL, Li S, Koplan JP 2013, Challenges for philanthropy and tobacco control in China (1986-2012). Tobacco Control vol. 22 Suppl 2, pp. ii4-8.

Roemer, R, Taylor, A and Larivier, J 2005, 'Origins of the WHO Framework Convention on Tobacco Control', American Journal of Public Health, vol. 95 no. 6, pp. 936-938.

Roemer, R 1993, Legislative Action to Combat the World Tobacco Epidemic, World Health Organization, Geneva, Switzerland.

Roemer, R 1982, Legislative Action to Combat the World Smoking Epidemic, world Health Organization, Geneva, Switzerland.

Royal College of Physicians 1962, Smoking and Health, Pitman Medical Publishing Co, London.

Schwartz RL, Wipfli HL, Samet JM. World No Tobacco Day 2011: India's progress in implementing the framework convention on tobacco control. Indian Journal of Medical Research vol. 133, pp. 455-457.

Saloojee, Y and Dagli, E 2000, 'Tobacco Industry Tactics for Resisting Public Policy on Health', Bulletin of the World Health Organization, vol. 78 no. 7, pp. 902-910.

Shibuya, K, Ciedierski, C, Guindon, E, et al. 2003, 'WHO Framework Convention on Tobacco Control', BMJ, vol. 327 pp. 154-157.

Stone, D. and Ladi, S. (2015) 'Global Public Policy and Transnational Administration', Public Administration

Streeck, W. and Thelen, K. 2005, Introduction. In: Streeck W, Thelen K, eds. Beyond Continuity Oxford, UK: Oxford University Press.

Taylor, A. L. and R. Roemer 1996, 'Programme on Substance Abuse: International Strategy for Tobacco Control' http://legacy.library.ucsf.edu/tid/hqt83c00 Accessed 11 Jun 2008

Thun, M, Peto, R, Boreham, J, et al. 2012, 'Stages of the Cigarette Epidemic on Entering its Second Century', Tobacco Control, vol. 21 no. 2, pp. 96-101. 
True JL, Jones BD, Baumgartner FR 2007, Punctuated Equilibrium Theory. In: Sabatier P, editor. Theories of the Policy Process. 2nd ed. Cambridge, MA: Westview Press; 2007.

Tumwine, J 2011, 'Implementation of the Framework Convention on Tobacco Control in Africa', International Journal of Environmental Research and Public Health, vol. 8 no. 11, pp. 4312-4331.

U.S. Department of Health Education and Welfare 1964, Smoking and Health, D. Van Nostrand Co, Princeton, NJ.

UN General Assembly, 2011, Political declaration of the High-level Meeting of the General Assembly on the Prevention and Control of Non-communicable Diseases. http://www.un.org/ga/search/view_doc.asp?symbol=A\%2F66\%2FL.1andLang=E

US National Clearinghouse for Smoking, 1973, Smoking and health programs around the world. http://legacy.library.ucsf.edu/tid/hli43f00

Wan X, Stillman F, Liu H, Spires M, Dai Z, Tamplin S, et al. 2013, Development of policy performance indicators to assess the implementation of protection from exposure to secondhand smoke in China. Tobacco Control vol. 22 Suppl 2, pp. ii9-15

Warner, KE and Tam, J 2012, 'The Impact of Tobacco Control Research on Policy', Tobacco Control, vol. 21 no. 2, pp.103-109.

Warren, CW, Lee, J, Lea, V, et al. 2009, 'Evolution of the Global Tobacco Surveillance System (GTSS) 1998-2008', Global Health Promotion, vol. 16 no. 2 Suppl, pp. 4-37.

Weishaar, H, Collin, J, Smith, K, et al. 2012, 'Global Health Governance and the Commercial Sector', PLoS Medicine, vol. 9 no. 6, pp. e1001249.

WHO. 2009, Smoke-free movies: from evidence to action. Geneva, Switzerland: WHO

WHO 2013a, Protocol to eliminate illicit trade in tobacco products. http://apps.who.int/iris/bitstream/10665/80873/1/9789241505246_eng.pdf WHO2013b, WHO Framework Convention on Tobacco Control: Guidelines for Implementation: Article 5.3, Article 8, Articles 9 and 10, Article 11, Article 12, Article 13, Article 14. http://apps.who.int/iris/bitstream/10665/80510/1/9789241505185_eng.pdf

WHO 2012, 2012 Global progress report on implementation of the WHO Framework Convention on Tobacco Control. Available from: <http://www.who.int/fctc/reporting/2012_global_progress_report_en.pdf>. [April 3 2013].

WHO 2011, WHO Report about Global Tobacco Epidemic, 2011, WHO, Geneva, Switzerland. 
WHO 2008, WHO Report on the Global Tobacco Epidemic, 2008: MPOWER Package, World Health Organization, Geneva, Switzerland.

WHO 2006, Constitution of the World Health Organisation, WHO, Geneva, Switzerland.

WHO 2003, WHO Framework Convention on Tobacco Control, WHO, Geneva, Switzerland.

WHO 2000, Committee of Experts Report on Tobacco Company Strategies to Undermine Tobacco Control Activities at the World Health Organisation. http://www.who.int/tobacco/en/who_inquiry.pdf

WHO 1976, Legislative Action to Combat Smoking Around the World. WHO, Geneva.

WHO 1970, WHA23.32 Health Consequences of Smoking, WHO, Geneva, Switzerland.

Wu T (ed) Tobacco Control Policy Analysis in China. London, UK: Word Scientific.2008. .

Yach, D 2014, 'The Origins, Development, Effects, and Future of the WHO Framework Convention on Tobacco Control', Lancet, vol. 383 no. 9930 pp. 1771-9

Yach, D and Bettcher, DW 2000, 'Globalization of the Tobacco Industry Influence and New Global Response', Tobacco Control, vol. 9 pp. 206-21.

\section{Acknowledgement}

Hadii Mamudu would like to thank the office of the president of East Tennessee State University for providing funding for an observational study of the $4^{\text {th }}$ meeting of the FCTC Conference of the Parties (COP4) in 2010 in Punta del Este, Uruguay.

\footnotetext{
${ }^{\mathrm{i}}$ Outliers include Malawi, which depends on tobacco for over $60 \%$ of its foreign exchange revenue, and the US. While the US has one of the strongest domestic tobacco control policies, reservations about trade and the difficulty of getting the necessary supermajority in the US Senate have prevented ratification The other nonratifying countries are: Andorra, Argentina, Cuba, Dominican Republic, Eritrea, Haiti, Indonesia, Monaco, Morocco, Mozambique, Somalia, Switzerland, and Zimbabwe. Still, the FCTC shares many elements with a 'policy regime' (Krasner, 1983), and it exhibits a similar dynamic to that within another international organizations, such as the EU, where leading tobacco control countries have uploaded their policies to the supranational level, which influences laggard countries (Nadelman 1990; Authors, 2008; Author 2012). ii MPOWER: Monitoring tobacco use and prevention policies, Protecting people from tobacco smoke, Offering help to quit tobacco use, Warning about dangers of tobacco use, Enforcing ban on tobacco advertising, promotion and sponsorship, Raising tobacco taxes.
} 